\title{
Blood flukes (Digenea: Aporocotylidae) of walking catfishes (Siluriformes: Clariidae): new genus and species from the Mekong River (Vietnam) with comments on related catfish aporocotylids
}

\author{
Triet Nhat Truong ${ }^{1}$ and Stephen A. Bullard ${ }^{2}$ \\ ${ }^{1}$ Department of Aquaculture, Dongthap Community College, Dongthap, Vietnam; \\ ${ }^{2}$ Aquatic Parasitology Laboratory, Department of Fisheries and Allied Aquacultures, College of Agriculture, Auburn University, \\ Auburn, Alabama, USA
}

\begin{abstract}
Nomasanguinicola canthoensis gen. et sp. n. infects the branchial vessels of bighead catfish, Clarias macrocephalus Günther (Siluriformes: Clariidae), in the Mekong River near Can Tho, southern Vietnam. Nomasanguinicola differs from all other genera of fish blood flukes (Digenea: Aporocotylidae) by the combination of lacking body spines and by having an anterior sucker with two flanking columns of large denticles, an intestine comprising several short papilla-like caeca, an inverse U-shaped uterus, and an ootype located near the separate genital pores. The new species has an ootype that is posterior to the level of the female genital pore. That feature most easily differentiates it from the only other putative aporocotylid species having an anterior sucker with two flanking columns of large denticles, Plehniella dentata Paperna, 1964 and Sanguinicola clarias Imam, Marzouk, Hassan et Itman, 1984, which have an ootype that is lateral (P. dentata) or anterior (S. clarias) to the level of the female genital pore. These two species apparently lack extant type materials, infect North African catfish, Clarias gariepinus (Burchell), and herein are considered incertae sedis, but likely comprise species of Nomasanguinicola. An updated list of hosts, sites of infection and geographic localities for the six species and three genera of blood flukes that mature in catfishes is provided. The new species is the first fish blood fluke recorded from Vietnam and only the third reported from a walking catfish (Clariidae).
\end{abstract}

Keywords: taxonomy, Nomasanguinicola canthoensis, Sanguinicola clarias, Plehniella dentata, Clarias macrocephalus, South East Asia

The nominal 'blood flukes' (Digenea: Aporocotylidae) that mature in the blood vascular system of freshwater fishes total 24 species assigned to Sanguinicola Plehn, 1907 plus monotypic Acipensericola Bullard, Snyder, Jensen et Overstreet, 2008 and Plehniella Szidat, 1951 (see also Lebedev and Parukhin 1972), which comprise species that likely infect the body cavity of catfishes only (Szidat 1951; unpublished data) (Table 1). To date, collectively, the freshwater fish aporocotylids have been documented to infect members of Cypriniformes (28 fish host species), Siluriformes (7), Esociformes (Esox lucius Linnaeus), Perciformes ( $5+2$ marine), Salmoniformes (4 species of Oncorhynchus Suckley), Characiformes [Prochilodus platensis (Valenciennes)], and Acipenseriformes [Polyodon spathula (Walbaum) and Acipenser oxyrinchus Mitchill].

The diversity of species presently assigned to Sanguinicola sensu lato that infect freshwater fishes is focused principally on cypriniforms, with nearly all parasite-host records deriving from members of the Cyprinidae (see Smith 1997a,b). Many fewer host records of non-cyprini- forms exist and a blaring exception is that of Sanguinicola maritimus Nolan et Cribb, 2005, which infects marine wrasses (Labridae) of south Australia (Nolan and Cribb 2004).

Compared to the blood flukes of carps, all of which are currently assigned to Sanguinicola, those of catfishes (Siluriformes), including putative species of Sanguinicola and Plehniella, are few. These five aporocotylids infect the blood (Woodland 1923, 1924, Odhner 1924, Paperna 1964, 1996) and body cavity (Szidat 1951, Guidelli et al. 2002) of seven catfishes assigned to three families and six genera (Table 1). Some of these hosts are valued aquaculture species, e.g. walking catfishes (species of Clarias Scopoli), and because blood flukes are known pathogens of cultured fishes (Bullard and Overstreet 2002), knowledge on their taxonomic diversity, hosts and geographic distributions is important to disease diagnostics and prevention in warm-water culture systems.

Herein, we report the first record of a fish blood fluke from Vietnam and describe specimens collected from the

Address for correspondence: S.A. Bullard, Aquatic Parasitology Laboratory, Department of Fisheries and Allied Aquacultures, College of Agriculture, Auburn University, 203 Swingle Hall, Auburn, Alabama 36849, USA. Phone: +1 334844 9278; Fax +1 334 844 9208; E-mail: ash.bullard@auburn.edu 
Table 1. Blood flukes (Digenea: Aporocotylidae) of catfishes (Siluriformes).

\begin{tabular}{|c|c|c|c|c|}
\hline & Host & Site & Locality & Reference(s) \\
\hline \multirow[t]{2}{*}{$\begin{array}{l}\text { Sanguinicola chalmersi } \\
\text { Odhner, } 1924\end{array}$} & $\begin{array}{l}\text { Auchenoglanis occidentalis } \\
\text { (Valenciennes) } \\
\text { (Claroteidae) }\end{array}$ & blood, heart & Sudan, Africa & $\begin{array}{l}\text { Woodland } 1923, \\
\text { Odhner } 1924, \\
\text { Khalil } 1969,1971, \\
\text { Paperna } 1996\end{array}$ \\
\hline & $\begin{array}{l}\text { Synodontis schall } \\
\text { (Block and Schneider) } \\
\text { (Mochokidae) }\end{array}$ & $\begin{array}{l}\text { mesenteric and } \\
\text { branchial blood } \\
\text { vessels }\end{array}$ & $\begin{array}{l}\text { Cairo and Giza } \\
\text { fish markets, Egypt }\end{array}$ & $\begin{array}{l}\text { Woodland } 1923 \text {, } \\
\text { Imam et al. } 1984\end{array}$ \\
\hline \multirow[t]{2}{*}{$\begin{array}{l}\text { Sanguinicola clarias } \\
\text { Imam, Marzouk, Hassan et Itman, } 1984 \\
\text { incertae sedis }\end{array}$} & $\begin{array}{l}\text { Clarias gariepinus } \\
\text { (Burchell) } \\
\text { (Clariidae) } \\
\text { (as C. lazera) }\end{array}$ & $\begin{array}{l}\text { 'mesenteric and } \\
\text { other blood vessels' }\end{array}$ & $\begin{array}{l}\text { Cairo and Giza } \\
\text { fish markets, Egypt }\end{array}$ & Imam et al. 1984 \\
\hline & & not specified & $\begin{array}{l}\text { Beni-Suef fish market, } \\
\text { Egypt }\end{array}$ & $\begin{array}{l}\text { Imam and El-Askalany } \\
1990\end{array}$ \\
\hline \multirow[t]{3}{*}{$\begin{array}{l}\text { Plehniella coelomicola } \\
\text { Szidat, } 1951\end{array}$} & $\begin{array}{l}\text { Iheringichthys labrosus } \\
\text { (Lütkin) } \\
\text { (Pimelodidae) }\end{array}$ & body cavity & $\begin{array}{l}\text { La Plata River, } \\
\text { Argentina }\end{array}$ & Szidat 1951 \\
\hline & $\begin{array}{l}\text { Pimelodus maculatus } \\
\text { Lacépède } \\
\text { (Pimelodidae) } \\
\text { (as } P \text {. clarias) }\end{array}$ & body cavity & $\begin{array}{l}\text { La Plata River, } \\
\text { Argentina }\end{array}$ & $\begin{array}{l}\text { Szidat } 1951, \\
\text { Lunaschi } 1985\end{array}$ \\
\hline & $\begin{array}{l}\text { Pimelodus albicans } \\
\text { (Valenciennes) } \\
\text { (Pimelodidae) }\end{array}$ & body cavity & $\begin{array}{l}\text { La Plata River, } \\
\text { Argentina }\end{array}$ & Lunaschi 1985 \\
\hline $\begin{array}{l}\text { Plehniella dentata } \\
\text { Paperna, } 1964 \text { incertae sedis }\end{array}$ & $\begin{array}{l}\text { Clarias gariepinus } \\
\text { (Burchell) } \\
\text { (Clariidae) } \\
\text { (as C. lazera) }\end{array}$ & $\begin{array}{l}\text { 'intestine' } \\
\text { (probably } \\
\text { mesenteric vessels) }\end{array}$ & $\begin{array}{l}\text { Lake Tiberia and Hule } \\
\text { Nature Reserve, Israel }\end{array}$ & Paperna 1964 \\
\hline $\begin{array}{l}\text { Plehniella platyrhynchi } \\
\text { (Guidelli, Isaac et Pavanelli, 2002) comb. n. } \\
\text { (originally Sanguinicola) }\end{array}$ & $\begin{array}{l}\text { Hemisorubim platyrhnchos } \\
\text { (Valenciennes) } \\
\text { (Pimelodidae) }\end{array}$ & body cavity & Paraná River, Brazil & Guidelli et al. 2002 \\
\hline Nomasanguinicola canthoensis gen. et sp. n. & $\begin{array}{l}\text { Clarias macrocephalus } \\
\text { Günther } \\
\text { (Clariidae) }\end{array}$ & branchial vessels & $\begin{array}{l}\text { Can Tho fish market, } \\
\text { Vietnam } \\
\text { (Mekong River) }\end{array}$ & present study \\
\hline
\end{tabular}

branchial vessels of bighead catfish, Clarias macrocephalus Günther (Siluriformes: Clariidae) as a new species. We also propose a new genus to accommodate this new species and use its diagnostic characters to focus attention to the only other nominal clariid blood flukes, both of which reportedly infect North African catfish, Clarias gariepinus (Burchell): Plehniella dentata Paperna, 1964 and Sanguinicola clarias Imam, Marzouk, Hassan et Itman, 1984) (see Paperna 1964, Imam et al. 1984).

\section{MATERIALS AND METHODS}

The infected catfish was captured locally from the Mekong River before being purchased from a fish market in Can Tho $\left(10^{\circ} 01^{\prime} 35^{\prime \prime} \mathrm{N} ; 105^{\circ} 47^{\prime} 12^{\prime \prime} \mathrm{E}\right)$, Vietnam, kept alive in a bucket of ambient water, euthanized by spinal severance and necropsied on 5 January 2011. The heart, gill arches and associated branchial vessels were removed, isolated in separate sample bags and exposed to freshwater heated to $60^{\circ} \mathrm{C}$ immediately before filling the sample bag with and being stored in $10 \%$ neutral buffered formalin (n.b.f.).

In the laboratory at Auburn University, the fixed contents of the sample bag were examined for the presence of aporocotylids with aid of a stereo-dissecting microscope. Resulting aporocotylid specimens intended as stained, whole mounted specimens were removed from n.b.f., rinsed thoroughly with distilled water and cleaned with fine brushes to remove any debris, stained overnight in Van Cleave's hematoxylin with several additional drops of Ehrlich's hematoxylin, made basic at $70 \%$ ethanol with lithium carbonate and butylamine, dehydrated, cleared in clove oil, and permanently mounted on glass slides using Canada bal- sam. Illustrations of stained, whole-mounted specimens were made with the aid of a Leica DM-2500 equipped with differential interference contrast optical components and a drawing tube. Measurements were obtained by using a calibrated ocular micrometer and are herein reported in micrometres $(\mu \mathrm{m})$ as a range followed by, in parentheses, the mean and number of measurements taken. Scientific names including taxonomic authorities and dates for fishes follow Eschmeyer (2012). Common names are taken from FishBase (Froese and Pauly 2012). Higher level fish classification and nomenclature follows Nelson (2006). Nomenclature for the Aporocotylidae follows Bullard et al. (2009). Brown (1956) was used to help construct the genus name and specific epithet.

\section{RESULTS}

Nomasanguinicola gen. $\mathrm{n}$.

Figs. 1-9

Diagnosis. Body of adult approximately $<8 \times$ longer than wide, dorsoventrally flattened, lacking posterolateral protuberance, more rounded posteriorly than anteriorly, ventrally concave, lacking tegumental body spines ('Marginalstacheln') and rods and bristles ('Stäbchen-Börstchen'). Rosethorn-shaped spines in posterior body end absent. Ventrolateral nerve cords and dorsolateral nerve cords present; ventrolateral nerve cord extending nearly entire body length, appearing slightly subterminal, with commissures anteriorly and posteriorly.

Anterior sucker present, demarcated from body by posterior constriction of tegument, an obvious proboscis 
accommodating mouth, armed with denticles; denticles peg-like, having a broadly rounded proximal base and narrowing distally to form a slightly recurved tip, directing posteroventrally, forming two columns of four denticles each and flanking the mouth. Mouth a minute pore, medioventral, subterminal. Pharynx present, a minute muscular region surrounding terminus of oesophagus at level of anterior sucker. Oesophagus medial, without loops or extensive convolutions, $<1 / 4$ of body length, including anterior and posterior swellings, lacking obvious oesophageal gland that stains differentially and has refractive acini (cf. Cardicola spp.), connecting with intestinal ramification anterodorsally. Intestine comprising several short papilla-like caeca approximately $<1 / 10$ of oesophagus length. Caeca lacking diverticula or secondary rami but having uneven outline.

Testis single, extending from a region posterior to caeca to ovary, $<1 / 3$ of body length, an extensively convoluted mass of basophilic testicular tissue, sperm, and vasa efferentia presenting as field with laterally directing lobes, not extending lateral to ventrolateral nerve cords; vasa efferentia coalescing at posteroventral margin of testis. Auxiliary external seminal vesicle absent. Stylet associated with cirrus absent. Cirrus-sac present, surrounding enlarged seminal vesicle. Male genital pore dorsal, sinistral, post-gonadal, slightly lateral to midline.

Ovary single, medial, margins expanding laterad and resembling 'butterfly wings', as wide or wider than testicular field, occupying posterior $1 / 4$ of body immediately posterior to testicular field. Vitellarium follicular, coextensive with alimentary tract, gonads and reproductive tracts from level of pharynx to ovary; common vitelline duct prominent, medial, forming a wide duct at level of ventrolateral nerve commissure, extending posteriad along midline, ventral to gonads and male reproductive tract. Oviduct emanating from posteromedial ventral surface of ovary, expanding in proximal portion to form an oviducal seminal receptacle, connecting with distal portion of vitelline reservoir before joining with ootype; ootype longer than wide, located approximately at level of genital pores. Laurer's canal not evident.

Uterus inverse U-shaped, lacking coils or extensive convolutions along its length, having approximately equal-length ascending and descending segments; uterine seminal receptacle not evident; uterine eggs spheroid, lacking appendages or filaments, lacking triangular habitus. Metraterm indistinct. Female genital pore near level of male genital pore. In blood vascular system of 'walking catfishes' (Siluriformes: Clariidae).

Differential diagnosis. Ventrolateral tegumental body spines absent. Anterior sucker present, with denticles; denticles peg-like, directing posteroventrally, forming a column per each side of mouth. Pharynx present, minute, at terminus of oesophagus. Oesophagus $<1 / 4$ of body length, including anterior and posterior swellings. Intes- tine comprising several short papilla-like caeca. Auxiliary external seminal vesicle and stylet associated with cirrus absent. Cirrus-sac present. Ovary butterfly wingshaped. Common vitelline duct medial, forming a wide duct at level of ventrolateral nerve commissure. Oviduct expanding proximally to form oviducal seminal receptacle; ootype located approximately at level of genital pores. Laurer's canal absent. Uterus inverse U-shaped, lacking coils, having approximately equal-length ascending and descending segments. Genital pores separate.

Type species: Nomasanguinicola canthoensis sp. n.

Ety mology: The Greek 'nomas' for nomad or wanderer refers to the terrestrial affinity of Clarias spp. (so-called 'walking catfishes') as well as alludes to the natural history of species assigned to Nomasanguinicola as probably divergent from those of Sanguinicola.

Remarks. The new genus differs from marine aporocotylid genera that include species infecting bony fishes (Euteleostei) by the combination of lacking ventrolateral transverse rows of tegumental body spines and by having an intestine comprising several short caeca rather than elongate, paired anterior and posterior caeca. It differs from the blood fluke genera including species that infect chondrichthyans by lacking robust, C-shaped lateral tegumental body spines and a Laurer's canal. Nomasanguinicola is easily differentiated from the other aporocotylid genera including species that infect freshwater fishes, i.e. Sanguinicola, Plehniella and Acipensericola, by characteristics of the anterior sucker, body spination, oesophagus, intestine, and genitalia. It most closely resembles Sanguinicola sensu lato by having an anterior oesophageal swelling, a prominent common vitelline duct that is medial and dorsal to the testis and genital ducts (Ejsmont 1926), a lobed testis that is post-caecal, and a 'doublewinged' or 'butterfly-shaped' ovary that is primarily posttesticular.

Nomasanguinicola differs from Sanguinicola mostly notably by the spination of the anterior sucker. We regard the presence of two columns of denticles and flanking the mouth as the marquee feature that differentiates Nomasanguinicola from all other blood fluke genera. Other aporocotylids have minute, straight spines typically arranged in concentric rows distributing anterior to the mouth (Meade and Pratt 1965, Schell 1974, Guidelli et al. 2002, Bullard 2012); however, those spines should not be confused with the denticles described herein and diagnostic for Nomasanguinicola. Moreover, we doubt that the denticles of Nomasanguinicola and the concentric, minute spines of aporocotylids are homologous. Abundant morphological evidence suggests that the latter spines are paedomorphic and homologous to the spines of the specialized penetration organ of aporocoytylid cercariae (Cribb et al. 2011). Likewise, the tri-radiate 'tooth-like mouth apparatus' that Ejsmont (1926) observed in S. armata and that Rašín 
(1929) observed in S. volgensis (as Janickia volgensis) should not be confused with the denticles described herein for the type species of Nomasanguinicola.

Plehniella, the only other aporocotylid genus that includes species infecting catfishes, differs from Sanguinicola and Nomasanguinicola by lacking lateral tegumental body spines or denticles associated with the anterior sucker and by having an ovoid body (rather than an elongate), a gut comprising six short caeca (rather than four or five), testicular lobes angled at $45^{\circ}$ from the midline and that each form a V-shape, a massive seminal vesicle enveloped by a glandular region, and a compact ovary that is entirely post-testicular and deeply-lobed. An ecologically unique attribute of species of Plehniella is that they mature in the body cavity of catfishes (Table 1); whereas the other freshwater aporocotylid genera include species infecting the blood. All of the blood flukes that have been reported to infect the body cavity of freshwater fishes infect pimelodid catfishes and all are assigned to Plehniella. No blood fluke infecting the body cavity of a species of Clariidae has been reported to date. The taxonomic status of Plehniella and its species will be treated in greater detail elsewhere (in preparation, SAB).

Acipensericola, which accommodates the blood flukes of basal actinopterygians (Acipenseriformes) has a bowlshaped anterior sucker, robust peg-like lateral tegumental spines, a column of testes, and a Laurer's canal, among other diagnostic features (Bullard et al. 2008).

\section{Nomasanguinicola canthoensis $\mathrm{sp} . \mathrm{n}$.}

Figs. 1-9

Diagnosis of adult based on light microscopy of four whole-mounted specimens: With characters of Nomasanguinicola (see above). Body elongate oval in shape, 840-1060 (943; 4) long, 230-250 (240;4) wide or $3.5-4.6(3.9 ; 4) \times$ longer than wide; body-margin straightened, not constricted ventrally in any specimen studied, having regularly-spaced aggregates of tegumental papillae; papillae aggregates having approximately 3-6 papillae each approximately 1 long and 1 wide, near limits of light microscopy (Figs. 1, 2).

Ventrolateral nerve cords $5-10(8 ; 4)$ wide near midbody at widest level, difficult to trace for most of length in most specimens, $30-38(35 ; 3)$ or $12-17 \%(15 \% ; 4)$ of body width from body margin, contiguous at body ends, becoming confluent with paired cord 18-20 $(19 ; 4)$ or $2 \%$ of body length from posterior body end; secondary branches and dorsolateral nerve cords not evident; commissure of ventrolateral nerve cord 105-123 $(114 ; 4)$ or $12-13 \%(12 \% ; 4)$ of body length from anterior body end, $50-65(58 ; 3)$ across width of worm or $22-26 \%(24 \% ; 4)$ of body width, 8 (4) in diameter, perpendicular to long axis of body, coursing dorsal to oesophagus (Fig. 1).

Ventral tegumental sensory papillae present, distributing across ventral surface of body from level of anterior sucker to posterior end, approximately 3 in diameter, ap- parently lacking cilia but having a central pore-like structure that is less basophilic than surrounding tegument. Dorsal tegumental sensory papillae not evident with light microscopy.

Anterior sucker base width $38-40(39 ; 4)$ or $16-17 \%$ $(16 \% ; 4)$ of body width, $18-23(22 ; 4)$ long or $1.7-2.1$ $(1.8 ; 4) \times$ wider than long; terminal papillae on anterior margin of anterior sucker present, paired, each approximately 1 long and 1 wide; denticles of anterior sucker approximately 2 (4) wide, with each flanking column 12-18 $(16 ; 4)$ long or $52-100 \%(74 \%$; 4) of anterior sucker length (Figs. 1, 3, 5-7). Mouth 2 (4) in diameter, medioventral, $4-6(5 ; 4)$ or $17-33 \%(22 \%$; 4$)$ of anterior sucker length from anterior end; pharynx minute, approximately 7 long and 4 wide, comprising an oblong enveloping region surrounding distal end of oesophagus at level of anterior sucker, not extending posteriad along oesophagus beyond posterior margin of anterior sucker, indistinct, in our experience, at magnifications $<2000 \times$.

Oesophagus $230-305(265 ; 4)$ long or $27-30 \%$ (29\%; 4) of body length, beginning as a narrow tube extending posteriad $40-60(51 ; 4)$ or $4-6 \%(5 \% ; 4)$ of body length before connecting with anterior oesophageal swelling; anterior oesophageal swelling 29-35 $(33 ; 4)$ long or $14-24 \%(19 \% ; 4)$ of oesophagus total length, $10-18$ $(14 ; 4)$ wide or $4-7 \%(6 \% ; 4)$ of maximum body width, at level midway between ventrolateral nerve commissure and anterior sucker.

Oesophagus narrowing to 3 posterior to anterior oesophageal swelling and extending posteriad; posterior oesophageal swelling immediately anterior to caeca 23 (4) long or $8-10 \%(9 ; 4)$ of oesophagus length, 20-23 $(21 ; 4)$ wide or $1.3-2.3(1.8 ; 4) \times$ maximum oesophagus width.

Oesophagus wall approximately 2 thick at level of commissure of ventrolateral nerve cord, approximately 5 thick at level of posterior oesophageal swelling; connecting with intestine dorsomedially. Oesophageal gland not clearly differentiated from surrounding parenchyma in any specimen examined.

Intestine star-shaped, having five clearly-differentiated caeca in all specimens examined; caeca length measuring (clockwise from oesophagus-intestine connection) 20-30 (25; 3), 20-30 (25; 3), 25-30 (27; 3), 20-33 (26; 3), and $17-25(21 ; 3)$ or approximately $2-3 \%$ of body length and $6-9 \%$ of oesophagus length, caeca base width measuring (clockwise from oesophagus-intestine connection) 13-16 (14; 3), 13-14 (13; 3), 12-18 (15; 3), 10-18 (13; 3), and $10-25(16 ; 3)$ or approximately $5-8 \%$ of maximum body width; postcaecal distance $240-320(276 ; 4)$ or $28-32 \%$ $(29 \% ; 4)$ of body length (Figs. 1, 4).

Genitalia (Figs. 1, 8, 9) restricted to posterior quarter of body, primarily occupying space between nerve cords. Testicular field comprising a mass of testicular tissue, sperm and vasa efferentia, approximately rectan- 


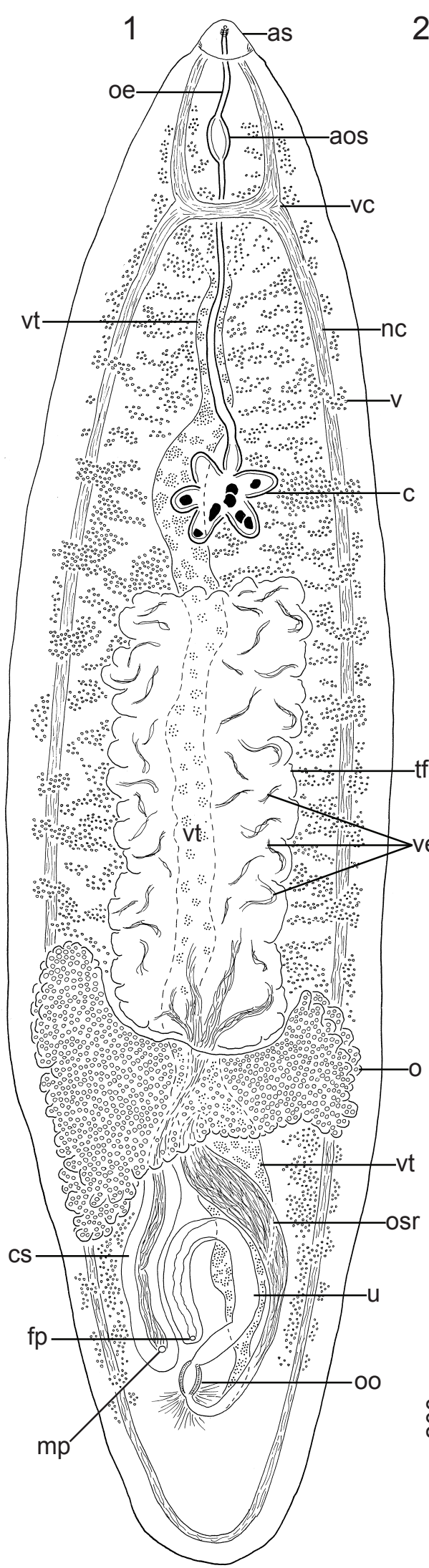

2

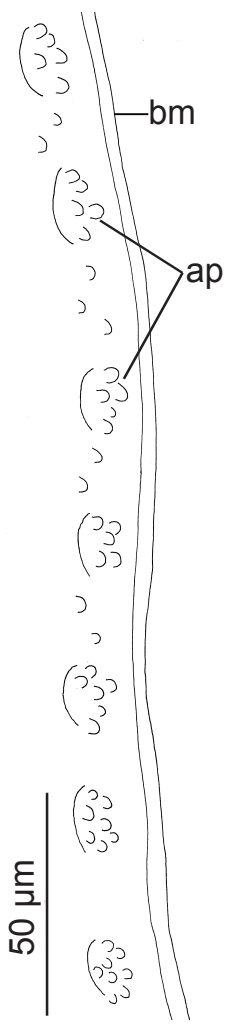

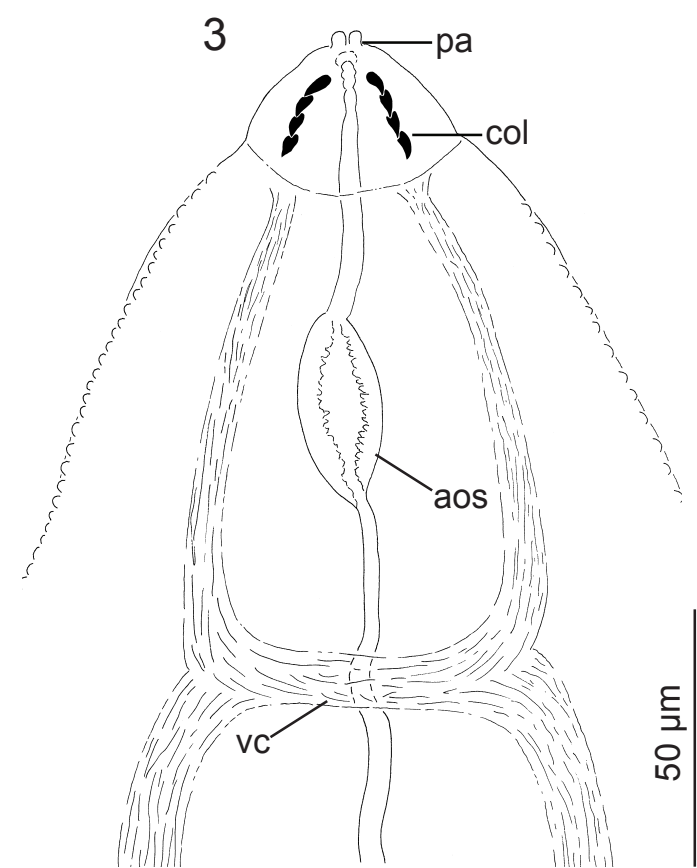

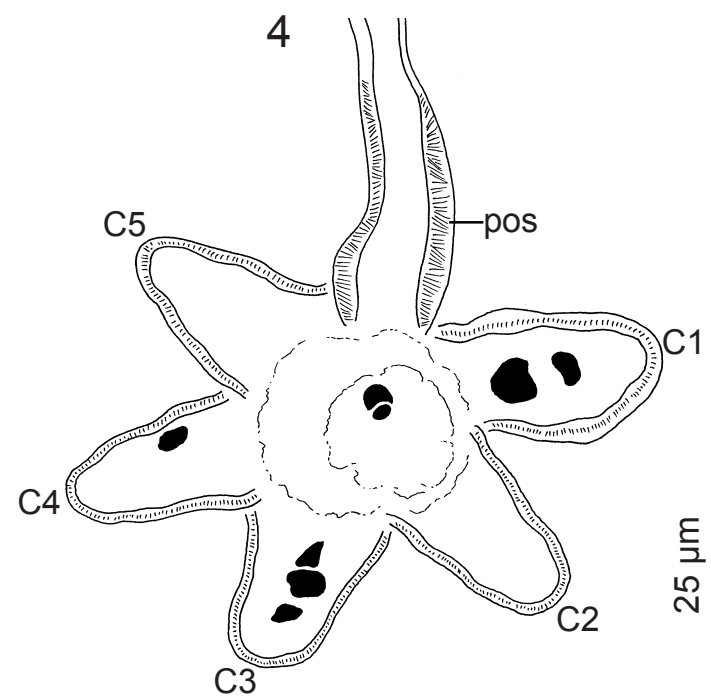

Figs. 1-4. Nomasanguinicola canthoensis gen. et sp. n. from branchial vessels of bighead catfish, Clarias macrocephalus, from the Mekong River, Vietnam. Fig. 1. Holotype (USNPC No. 106968). Dorsal view. Fig. 2. Lateral body margin of paratype (USNPC No. 106969). Ventral view. Fig. 3. Anterior end of holotype (USNPC No. 106968). Ventral view. Fig. 4. High magnification view of star-shaped caeca of holotype (USNPC No. 106969). Ventral view. Abbreviations: aos - anterior oesophageal swelling; ap - papillae; as -anterior sucker; bm - body margin; c - caecum; C1-C5 - papilla-like caecae; col - sinistral column of denticles; cs - cirrus-sac; fp - female genital pore; $\mathrm{mp}$ - male genital pore; nc - nerve cord; o - ovary; oe - oesophagus; oo - ootype; osr - oviducal seminal receptacle; pa - showing papillae of anterior sucker; pos - posterior oesophageal swelling; $v$ - vitellarium; vc - anterior commissure of ventrolateral nerve cord; ve - vasa efferentia; vt - primary vitelline duct; $\mathrm{tf}$ - testicular field; $\mathrm{u}$ - uterus. 


\section{5}

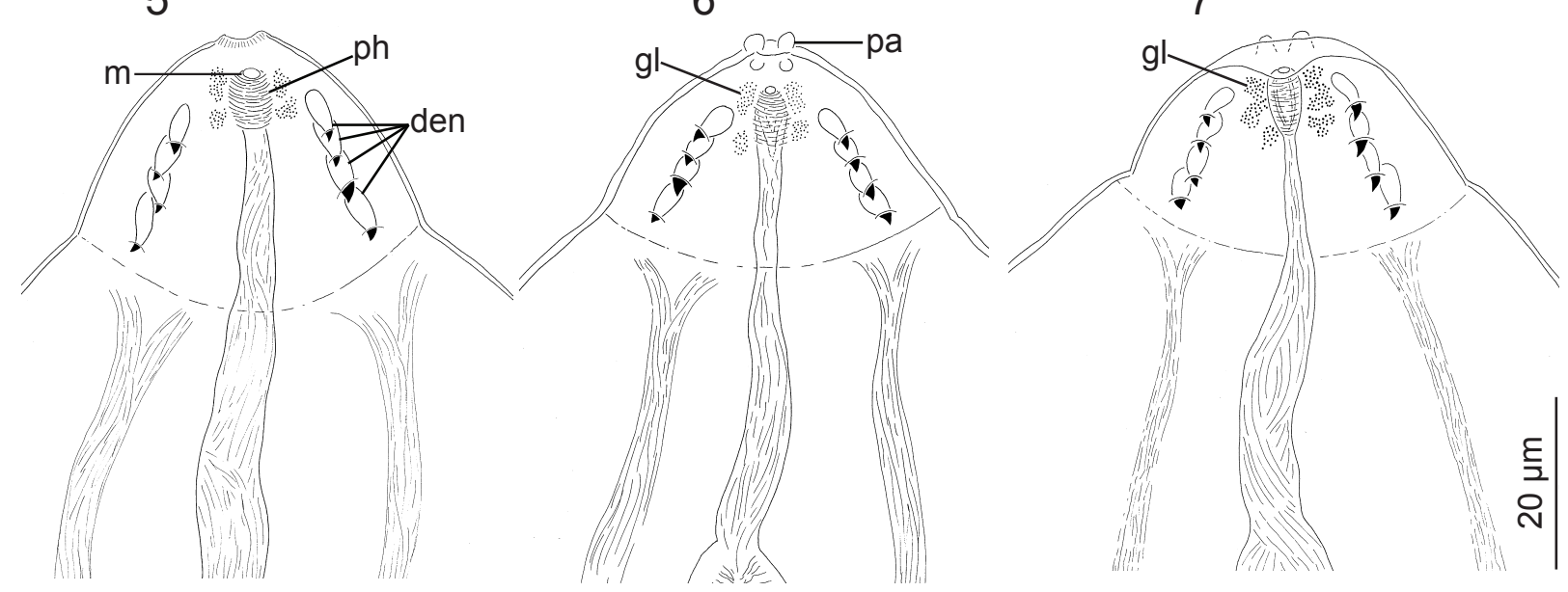

Figs. 5-7. Anterior sucker of Nomasanguinicola canthoensis gen. et sp. n. from branchial vessels of bighead catfish, Clarias macrocephalus from the Mekong River, Vietnam. Ventral view. Fig. 5. Paratype (USNPC No.106969). Fig. 6. Holotype (USNPC No. 106968). Fig. 7. Paratype (USNPC No. 106970). Abbreviations: den - denticles; gl - glandular area surrounding pharynx; $\mathrm{m}$ - mouth; pa - papillae associated with apex of anterior sucker; ph - pharynx.

gular in shape, entirely postcaecal, with slightly irregular lateral margins, 238-480 $(332 ; 4)$ long or $28-45 \%$ $(35 \% ; 4)$ of body length, $120-130(124 ; 4)$ in maximum width or $48-54 \%(52 \%$; 4$)$ of body width at level of midbody, 2.0-3.8 $(2.7 ; 4) \times$ wider than long; post-testicular space $325-405(358 ; 4)$ long or 33-43\% $(38 \%$; 4) of body length (Figs. 1, 8, 9).

Vasa efferentia difficult to trace, $4-8(7 ; 4)$ wide, an interconnecting meshwork of fine ducts entwining throughout testicular tissue, containing spermatozoa, extending primarily along ventral surface of testis, uniting in posterior region of testis to form vas deferens. Vas deferens an extremely thin-walled duct extending $80-85(83 ; 3)$ or $8-10 \%(9 \% ; 4)$ of body length posteriad, $8-12(10 ; 3)$ wide at level of posterior margin of testicular field, narrowing posteriorly to $2-7(4 ; 3)$ before connecting with cirrus sac and internal seminal vesicle, ventral to ovary, curving sinistrad, containing sperm in all specimens.

Cirrus-sac 22-28 (26; 3$)$ in maximum width or $10-11 \%$ $(10 \% ; 3)$ of body width, with wall $5-8(7 ; 3)$ thick; internal seminal vesicle robust, oblong, 126-160 (138; 3) long, $8-13(10 ; 3)$ wide or $12-16(13 ; 3) \times$ longer than wide, orienting diagonally posteriad. Gland surrounding seminal vesicle indistinct. Male genital pore approximately 8 wide, $90-150(123 ; 3)$ or $11-14 \%(13 \% ; 3)$ of body length from posterior body end, immediately posterolateral to female genital pore.

Ovary dorsal to vas deferens, having superficial lobes extending laterad in lateral regions of ovary near body margin, extending laterad beyond level of ventrolateral nerve cord, having dextral and sinistral halves of ovary measuring $84-158(114 ; 3)$ and $90-200(139 ; 3)$ long or approximately $10-17 \%(13 ; 3)$ of body length, $175-210(197 ; 3)$ in maximum width or $76-85 \%(82 ; 3)$ of body width,
0.4-1.0) $\times$ wider than long; post-ovarian space $123-150$ $(133 ; 3)$ long or $12-18 \%(14 \% ; 3)$ of body length (Figs. 1, $8,9)$.

Oviduct arching in dextral half of body posterior to ovary and medial to cirrus sac, $175-263(223 ; 3)$ long or $21-25 \%(24 \% ; 3)$ of body length, slightly shorter than combined length of vas deferens and cirrus sac, including a short proximal duct, a dilated portion (= oviducal seminal receptacle), and a narrow distal portion; short proximal duct emanating from posteroventral surface of ovary and extending posteriad $10-15(12 ; 3)$ before dilating, 2-5 (3) wide; oviducal seminal receptacle filled with sperm in all specimens, $100-140(120 ; 3)$ long or 38-69\% $(56 \% ; 3)$ of total oviduct length, $13-25(20 ; 3)$ wide or $5.6-7.8(6.3 ; 3) \times$ longer than wide, occupying space between cirrus-sac and dextral nerve cord, post-ovarian. Distal portion of oviduct $7-8(8 ; 3)$ wide or $32-62 \%$ $(42 ; 3)$ of oviducal seminal vesicle width, continuing posteriad approximately in parallel with dextral body margin before connecting with ootype.

Vitellarium primarily indistinct; secondary collecting ducts indistinct; primary vitelline duct originating in anterior region of body at level between ventrolateral nerve commissure, 610-770 $(710 ; 3)$ long, 15-28 $(22 ; 4)$ wide at level of caeca, $29-58(46 ; 3)$ wide at level of seminal vesicle; pre-vitelline duct distance $155-175(162 ; 3)$ or $15-17 \%(17 \% ; 3)$ of body length. Ootype $23-28(25 ; 3)$ long, 10-13 $(12 ; 3)$ wide, $1.9-2.3(2.1 ; 3) \times$ longer than wide, sinistral, immediately posterior to male genital pore, connecting with vitelline duct and oviduct on its posterior surface, orienting parallel with long axis of body (not transverse); post-ootype distance 103-125 (112; 3) or $10-13 \%(12 \% ; 3)$ of body length. Mehlis' gland 40-60 $(50 ; 3)$ wide, surrounding ootype and occupying region 
8
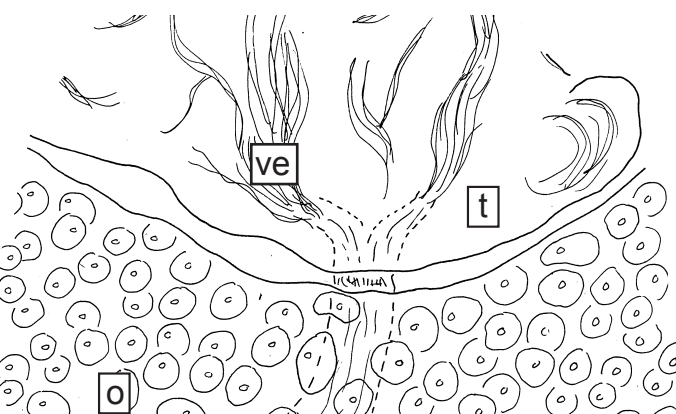

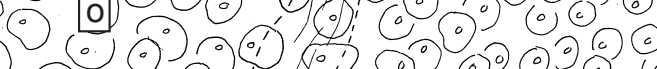

(0) 0000

$0 \% \bigcirc 0.000 \%$

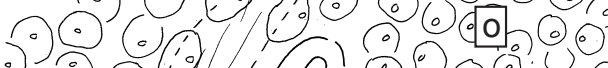

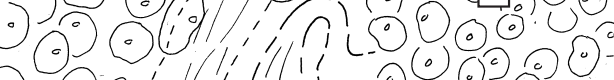

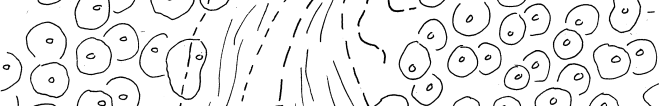

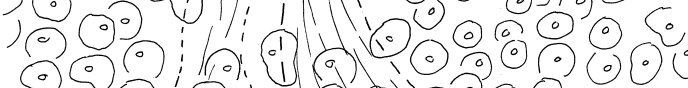

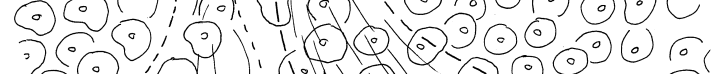
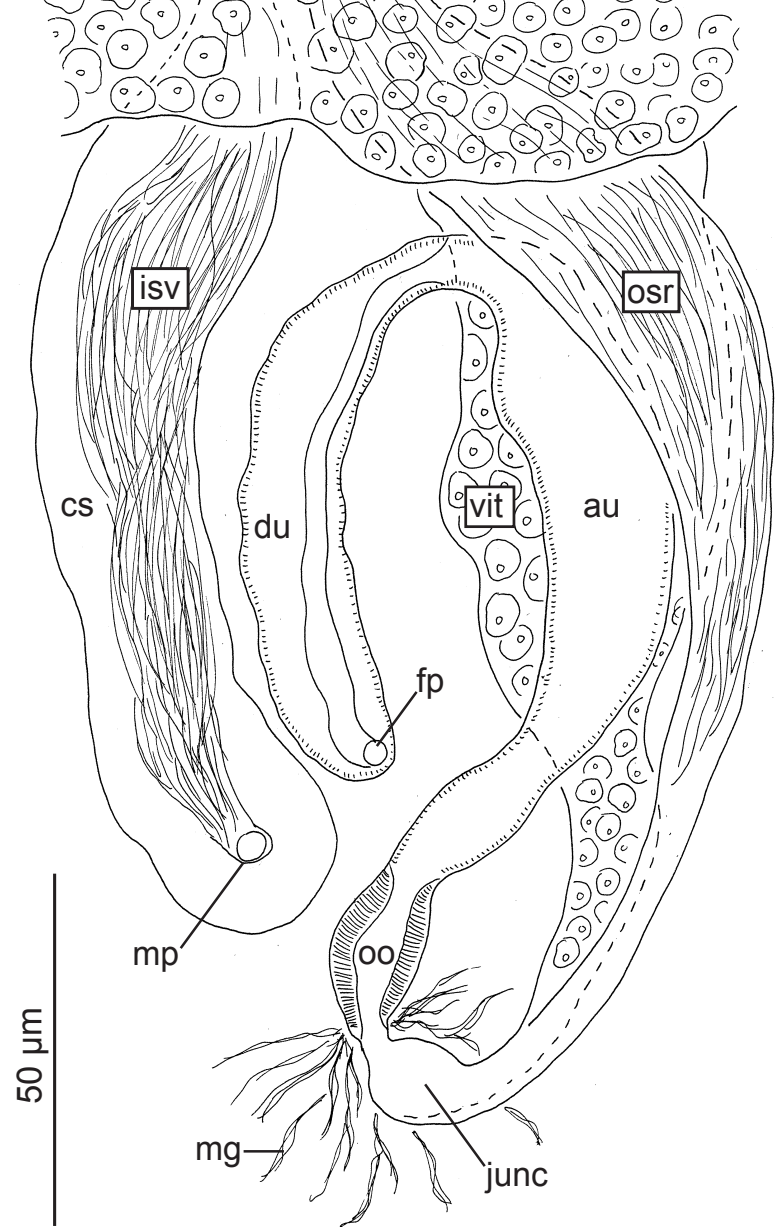

9


Figs. 8, 9. Genitalia of Nomasanguinicola canthoensis gen. et sp. n. from branchial vessels of bighead catfish, Clarias macrocephalus from the Mekong River, Vietnam. Fig. 8. Holotype (USNPC No. 106968). Dorsal view. Fig. 9. Paratype (USNPC No. 106969). Ventral view. Abbreviations: au - ascending segment of uterus; cs - cirrus-sac; du - descending segment of uterus; fp - female genital pore; isv - internal seminal vesicle; junc - junction of vitelline duct and oviduct; $\mathrm{mp}$ - male genital pore; mg - Mehlis' gland; oo - ootype; o - ovary; osr - oviducal seminal receptacle; vit - primary vitelline duct; $\mathrm{t}$ - testis; ve - vasa efferentia; vd - vas deferens. 
mostly posterior to connection of ootype with vitelline duct and oviduct.

Uterus inverse U-shaped, post-caecal, post-gonadal, occupying space between cirrus sac and oviducal seminal receptacle; ascending uterus $75-138(102 ; 3)$ long or $9-13 \%(10 ; 3)$ of body length, $17-40(26 ; 3)$ in maximum width; descending uterus $65-118(87 ; 3)$ long or $84-87 \%$ $(85 \% ; 3)$ ascending uterus length, $12-53(27 ; 3)$ in maximum width. Uterine eggs lacking thick shell, oblong, 16 (4) long, 10 wide (4) or $1.6 \times$ longer than wide. Female genital pore anteromedial to male genital pore, sinistral, postovarian, $133-158(144 ; 3)$ or $13-17 \%(15 \% ; 3)$ of body length from posterior body end. Excretory system indistinct.

Type and only host: Bighead catfish, Clarias macrocephalus Günther (Siluriformes: Clariidae).

Type locality: Fish market at Can Tho $\left(10^{\circ} 011^{\prime} 35^{\prime \prime N}\right.$; $\left.105^{\circ} 47^{\prime} 12 " E\right)$, Mekong River, southern Vietnam.

Site in host: Adults in branchial vessels.

Prevalence and intensity of infection: Four specimens infected one bighead catfish.

Specimens deposited: Holotype and one paratype at the United States National Parasite Collection (USNPC Nos. 106968-106970); one paratype at the Institute of Parasitology, Academy of Sciences of the Czech Republic, České Budějovice (IPCAS D-693).

Etymology: The specific epithet 'canthoensis' is for the type locality, Can Tho, Vietnam.

Remarks. We think that the nominal aporocotylids that infect clariids probably are congeners. The present study revealed some uncanny similarities between $N$. canthoensis and the published descriptions of two putatively distinct aporocotylids that infect a congeneric clariid (Clarius gariepinus) in Israel and Egypt, Plehniella dentata Paperna, 1964 and Sanguinicola clarias Imam, ElAskalany, Hassan et Itman, 1984. Most notably, N. canthoensis, $P$. dentata and $S$. clarias each have two columns of denticles (sensu Paperna [1964]; = 'rose thorne spines' of Imam et al. [1984]) embedded in the anterior sucker (= 'small sucker' of Paperna [1964]; = 'well defined snout' of Imam et al. [1984]) and flanking the mouth. Aside from perhaps Sanguinicola chalmersi Odhner, 1924 (see Discussion; Imam et al. 1984), these are the only nominal aporocotylids that reportedly have two columns of denticles flanking the mouth.

Also noteworthy is that the published descriptions of these aporocotylids list the following characters, which are diagnostic for Nomasanguinicola: anterior sucker present, pharynx minute and located at terminus of oesophagus (fig. 2.3 of Imam et al. 1984), oesophagus $<1 / 4$ of body length, intestine comprising several short papilla-like caeca, auxiliary external seminal vesicle or cirrus stylet lacking, cirrus-sac present, ovary having butterfly wing shape, ootype at approximate level of genital pores, Laurer's canal absent, and separate genital pores. Specific detail of the oviduct needs confirmation in $P$. dentata and $S$. clarias, it likely expands proximally to form an oviducal seminal receptacle (fig. 1.1 of Imam et al. 1984; fig. 33 of Paperna 1964).

Moreover, the new species (see Description) and $S$. clarias, and probably $P$. dentata (see Discussion), differ from the type species of Sanguinicola (S. armata) and several other putative species of Sanguinicola by having an inverse U-shaped uterus that has both ascending and descending segments. Descriptions of putative species assigned to Sanguinicola reportedly have a uterus that is abbreviated, comprising a short ascending segment only between the ootype and female genital pore. This has been repeatedly described and confirmed in Sanguinicola armata Plehn, 1905 (type species) (see Plehn 1905, Woodland 1923, 1924, Odhner 1924, Ejsmont 1926, Ong and Shaharom 1995), as well as in the closely related Sanguinicola inermis Plehn, 1905 (see fig. 4 of Kirk and Lewis 1993).

Supporting reassignment of $P$. dentata also is that it has several key generic features that are lacking in Plehniella coelomicola Szidat, 1951 (type species): denticles, a testis without V-shaped lobes, a seminal vesicle that reportedly lacks a glandular enveloping region, and an ovary that reportedly lacks deep lobes. These comprise features that make its assignment to Plehniella dubious, while not excluding it from Nomasangunicola. The new species is most easily differentiated from $P$. dentata and $S$. clarias by having an ootype that is posterior to the female genital pore, whereas $P$. dentata and $S$. clarias have an ootype that is lateral (Paperna 1964) or slightly anterior (Imam et al. 1984) to the female genital pore, respectively.

\section{DISCUSSION}

At the time of the writing of this manuscript, no extant type materials could be located for Plehniella dentata and Sanguinicola clarias. The only reported type material for P. dentata was the holotype (No. 2044), and it may have been destroyed during a 1983 fire in Ilan Paperna's laboratory in Eilat, Israel. Regarding S. clarias, Imam et al. (1984) did not report deposition of type materials and we cannot locate type materials for $S$. clarias. Hence, new specimens sourced from the type host and type localities of each need re-collection and re-description. Pending those results, we regard $P$. dentata and $S$. clarias as incertae sedis, likely representing a single species or two closely related species of Nomasanguincola. Below, however, we intend to offer a few helpful comments to those attempting to identify specimens of these putative species. Although clearly differentiated from the new species, some features reported by Paperna (1964) and Imam et al. (1984) need confirmation because they seem strikingly uncharacteristic for fish blood flukes related to members of Sanguinicola, Nomasanguinicola, or Plehniella.

Paperna's (1964) diagnostic description of $P$. dentata was based on two stained, whole-mounted specimens 
collected from the 'intestine' (presumably the mesenteric blood vessels) of two North African catfish, Clarias gariepinus (Burchell, 1822), (as C. lazera) (Sliluriformes: Clariidae) sampled at Lake Tibeiras and at Hule Nature Reserve (Israel). Regarding the uterus, Paperna (1964) may have misinterpreted its course because he illustrated it as distally swollen with sperm, extending anteriad, and ending immediately posterior to the ovary. No nominal species of the Aporocotylidae has a uterus including a thin-walled, distal portion serving as a uterine seminal receptacle and no nominal species of Sanguinicola or Plehniella reportedly has a female genital pore that opens dorsomedially at level of the ovary.

Paperna's interpretation of the uterus may have derived from previous descriptions of $S$. armata (see Ejsmont 1926), wherein the uterus is abbreviated, extending anteriad only a short distance from the ootype before opening dorsally at level of the male genital pore. It seems likely, however, given the anatomy of other aporocotylids, that the swollen part of the duct illustrated and labeled by Paperna (1964) as the uterus was actually the proximal portion of the oviduct functioning as an oviducal seminal receptacle, which many aporocotylids have. We deduce this also because the feature labeled as the uterus by Paperna is in the precise location as the oviducal seminal receptacle in Imam et al.'s (1984) description of the blood fluke from this host species as well as in our description of $N$. canthoensis. Hence, we suspect that Fig. 33 of Paperna (1964) mislabels the oviduct as the uterus. In addition, we think that Paperna's Fig. 33 shows that the female genital pore in $P$. dentata opens lateral to the ootype and the male genital pore is anteromedial to the ootype.

Regarding the intestinal caeca, Paperna (1964) clearly illustrated and reported that $P$. dentata had four short, symmetrical caeca comprising the intestine. However, the caeca of species of Sanguinicola, Plehniella, and Nomasanguinicola are easily missed: the wall of the caeca is thin, delicate, refractive to staining, and unlike that of other aporocotylids that infect marine fishes, which have a thick, refractive, well-staining caecal wall that is typically obvious even if specimens are not studied alive, heat-killed, or wellstained. Moreover, we observed that in some specimens of $N$. canthoensis, the gut can be easily misinterpreted as having only four caeca, rather than five, because the anteriormost caecum can be immediately dorsal to the posterior oesophageal swelling and obscured by it.

Other features of $P$. dentata reported by Paperna (1964) included body size and shape, lateral tegumental body spines absent (likening it to species of Plehniella and Nomasanguinicola), mouth opening at terminus of small anterior sucker, four denticles flanking mouth and increasing in size anteriorly to posteriorly, oesophagus dilated anteriorly, male genital pore near ootype, and ovary bilobed. All these features correspond well with the generic diagnosis provided herein for Nomasanguinicola.
Imam et al.'s (1984) description of S. clarias was based on ten whole-mounted specimens collected from the mesenteric and other blood vessels and heart of C. gariepinus from Cairo and Giza, Egypt. There are several key features that need confirmation in this species upon recollection of voucher materials. First is that their narrative description of $S$. clarias seems to be reversed, i.e. their fig. 1 is likely a dorsal view. Regarding the lateral tegumental spines, Imam et al. (1984) reported that $S$. clarias has a tegument provided with regularly arranged marginal spines, but spines were not illustrated, measured, or counted.

In $N$. canthoensis, dense clusters of papillae-like tegumental protrusions along the ventrolateral body margin give the impression of spines; however, spines need to be confirmed in $S$. clarias. Again, given the uncanny morphological similarity between $P$. dentata and S. clarias, both from the same catfish species in the same geographic region, and given that Paperna (1964) did not report tegumental spines, the presence of such spines in $S$. clarias would certainly be diagnostic.

Regarding a pharynx, Imam et al. (1984) reported that S. clarias had an elongated pharynx surrounding a portion of the oesophagus. Figures 1 and 3 of Imam et al. (1984) show an expansion of the oesophagus that seems morphologically comparable to the luminal expansion (= anterior oesophageal swelling) described by Paperna (1964) for $P$. dentata and by us herein for $N$. canthoensis. That this region comprises a true pharynx, i.e. a muscular bulb surrounding the oesophagus, rather than a lateral expansion of the lumen of the oesophagus needs confirmation since the presence of a pronounced muscular pharynx is likely a feature of generic significance within Aporocotylidae, and indeed a minute pharynx is present in N. canthoensis. It is also possible that the region is weakly muscular and that the feature is homologous to a pharynx but presents as a pliable oesophageal wall.

Ejsmont (1926) also identified an area in the anterior portion of the oesophagus that he labeled a pharynx. Woodland (1923) illustrated an anterior oesophageal swelling/dilation (labeled as a pharynx) that was distensible in the specimens of $S$. chalmersi that he studied. Herein, we call this region an oesophageal swelling because we do not see evidence of muscle surrounding the oesophagus. Regarding the intestinal caeca, Imam et al. (1984) reported an X-shaped intestinal caecum (including photomicrographs of the gut compared with other species of Sanguinicola). Regarding the testis, Imam et al. (1984) described the testis as having 6-7 pairs of acini located medially. Other features of $S$. clarias reported by Imam et al. (1984) included body size and shape, anterior sucker present and bearing denticles, mouth terminal, dilation of oesophagus (= posterior oesophageal swelling) at level of caeca present, cirrus sac large, distinct, ovary double winged, medial vitelline duct, and uterus inverse 
U-shaped. All of these features correspond well with the generic diagnosis provided herein for Nomasanguinicola.

Noteworthy also is that Imam et al. (1984) reported that one specimen of the catfish blood fluke Sanguinicola chalmersi Odhner, 1924 had seven denticles on either side of the mouth. No such denticles were illustrated or included in Odhner's (1924) original description, and it seems unlikely to us that this feature would vary intraspecifically, but this characteristic needs confirmation in newly collected specimens. All of the above would be beyond speculation if type materials for these taxa were extant but they apparently are not.

The above information extracted from the descriptions by Paperna (1964) and Imam et al. (1984) indicate that these flukes, both recorded from the same host species and from neighbouring geographic regions (Israel and Egypt), may be conspecific. Imam et al. (1984), apparently unaware of Paperna's (1964) description of $P$. dentata from the same host species, did not differentiate their new species from or mention P. dentata. New collections and studies of $P$. dentata and $S$. clarias from $C$. gariepinus (= type host) from Israel and Egypt (= type localities) could test the notion that these species are distinct as well as confirm their systematic position within Nomasanguinicola.

Regarding the life cycles, Paperna (1996) stated that eggs of $P$. dentata contain a fully developed miracidium when accumulated in the kidney of $C$. gariepinus. He speculated that perhaps the fluke exited the host via the urinary system. If so, this would be a significant evolutionary departure from the life cycles of other blood flukes wherein the miracidium develops in the gill before the egg hatches and the miracidium bores through the fish's gill epithelium. Perhaps this life history feature is worthy of future investigation, i.e. complementing routine histopathology with isolation and/or culture of aporocotylid eggs from kidney to confirm they contain ciliated larvae, whenever infected North African catfish are examined.

Acknowledgements. We thank Raphael Orélis-Ribeiro (Department of Fisheries and Allied Aquacultures - FAA, Auburn University) for collating information on the GenBank sequences pertaining to aporocotylids; Haitham Mohammed (FAA) for helping us in trying to locate Imam et al.'s (1984) type materials in Egypt and for connecting us with his Egyptian colleagues familiar with the likely whereabouts and present disposition of potential type materials and parasite collections at Cairo University; Arik Diamant (Israel Oceanographic and Limnological Research, National Center for Mariculture, Eilat, Israel) for informing the whereabouts and present disposition of Ilan Paperna's parasite collection and type materials; Eric Hoberg and Pat Pilitt (USNPC, Beltsville, Maryland, USA) for ensuring the safe deposition of our type materials and for loaning type and voucher aporocotylids; and Faizah Shaharom (Institute of Tropical Aquaculture, University Malaysia Terengganu, Malaysia) and Ong Bee Lee (Department of Veterinary Clinical Studies, University Putra Malaysia) for furnishing reprints of their redescription and related studies of $S$. armata. This is a contribution of the Southeastern Cooperative Fish Parasite and Disease Project (Department of Fisheries and Allied Aquacultures, Auburn University) and was supported in part by a fellowship awarded to TNT by the Mekong 1000 Program (cooperative agreement between Auburn University and the government of Vietnam) as well as the National Science Foundation's Division of Environmental Biology with funds from NSF-DEB grant numbers 1112729,1051106 , and 1048523 to SAB.

\section{REFERENCES}

Brown C.E. 1956: Composition of Scientific Words - A Manual of Methods and a Lexicon of Materials for the Practice of Logotechnics. Smithsonian Institution Press, Washington, D.C., 881 pp.

Bullard S.A. 2012: Cardicola langeli sp. n. (Digenea: Aporocotylidae) from heart of sheepshead, Archosargus probatocephalus, (Actinopterygii: Sparidae) in the Gulf of Mexico, with an updated list of hosts, infection sites and localities for Cardicola spp. Folia Parasitol. 60: 17-27.

Bullard S.A., Jensen K., Overstreet R.M. 2009: Historical account of the two family-group names in use for the single accepted family comprising the "fish blood flukes." Acta Parasitol. 54: 78-84.

Bullard S.A., Overstreet R.M. 2002: Potential pathological effects of blood flukes (Digenea: Sanguinicolidae) on pen-reared marine fishes. Proc. Gulf Caribb. Fish. Inst. 53: 10-25.

Bullard S.A., Snyder S.D., Jensen K., Overstreet R.M. 2008 : New genus and species of Aporocotylidae (Digenea) from a lower actinopterygian, the American paddlefish, Polyodon spathula, (Polyodontidae) from the Mississippi Delta. J. Parasitol. 94: 487-495.

Cribb T.H., Adlard R.D., Hayward C.J., Bott N.T., Ellis D., Evans D., Nowak B.F. 2011: The life cycle of Cardicola forsteri (Trematoda: Aporocotylidae), a pathogen of ranched southern bluefin tuna, Thunnus maccoyii. Int. J. Parasitol. 41: 861-870.

EjSMONT L. 1926: Morphologische, systematische und entwicklungsgeschichtliche Untersuchungen an Arten des Genus Sanguinicola Plehn. Bull. Int. Acad. Polonaise des Sci. Let., Serie B, Classe des Sciences Mathematiques et Naturelles, Sciences Naturelles, Year 1925, 9-10B: 877-966.

EschmeYeR W.N. 2012. Catalog of Fishes. http://research.calacademy.org/ichthyology/catalog. Last accessed 06 October 2012.

Froese R., Pauly D. (Eds.) 2012: FishBase. World Wide Web electronic publication. www.fishbase.org, 10/2012.

Guidelli G.M., IsaAC A., Pavanelli G.C. 2002: Sanguinicola platyrhynchi n. sp. (Digenea: Sanguinicolidae) parasite of visceral cavity of Hemisorubim platyrhynchos (Valenciennes, 1840) (Pisces: Pimelodidae) from the floodplain of the upper Paraná River, Brazil. Braz. J. Biol. 64: 801-806.

Imam E.A., El-Askalany M.A. 1990: An approach to helminth parasites of catfish (Clarias lazera) in Beni-Suef Governorate. Assiut Veterinary Medical Journal 24: 96-107.

Imam E.A., Marzouk M.S.M., Hassan A.A., Itman R.H. 1984: Studies on Sanguinicola sp. (Trematoda) of Nile fishes. Vet. Med. J. Egypt 32: 1-13.

Khalil L.F. 1969: Studies on the helminth parasites of freshwater fishes of the Sudan. J. Zool. London 158: 143-170. 
Khalil L.F. 1971: Checklist of the Helminth Parasites of African Freshwater Fishes. Tech. Comm. 42, Comm. Inst. Helm., C.A.B. England, $80 \mathrm{pp}$.

KIRK R.S., LEWIS L.W. 1993. The life-cycle and morphology of Sanguinicola inermis Plehn, 1905 (Digenea: Sanguinicolidae). Syst. Parasitol. 25: 125-133.

Lebedev V.I., Parukhin A.M. 1972. [New sanguinicolids (Trematoda) of fish from the Gulf of Mannar (coast of India).] Biol. Nauki (Mosc.) 4: 7-14. (In Russian.)

Lunaschi L.I. 1985: Helmintos parasitos de peces de agua dulce de la Argentina IV. Acerca de la Validez del género Plehniella Szidat, 1951 (Trematoda-Sanguinicolidae). Neotropica 31: 149-154.

Meade T.G., Pratt I. 1965: Description and life history of Cardicola alseae sp. n. (Trematoda: Sanguinicolidae). J. Parasitol. 51: $575-578$.

NeLson J.S. 2006: Fishes of the World. Fourth Edition. John Wiley and Sons, Inc., Hoboken, New Jersey, $601 \mathrm{pp}$.

Nolan M.J., Cribb T.H. 2004: The life cycle of Paracardicoloides yamagutii Martin, 1974 (Digenea: Sanguinicolidae). Folia Parasitol. 51: 320-326.

Odhner T. 1924: Remarks on Sanguinicola. Quart. J. Microscop. Sci. 68: 403-411.

Ong B.L., Shaharom F.M. 1995: Redescription of Sanguinicola armata Plehn, 1905 in locally produced grass carp (Ctenopharyngodon idella Cuvier and Valenciennes 1844) fingerlings. J. Biosci. 6: 1-9.

Paperna I. 1964: Parasitic helminths of inland-water fishes in Israel. Israel J. Zool. 13: 1-20.
Paperna I. 1996: Parasites, Infections and Diseases of Fishes in Africa. An update. Committee for Inland Fisheries of Africa (CIFA) Tech. Paper No. 31, FAO, Rome, 220 pp.

Plehn M. 1905: Sanguinicola armata und inermis (n. gen., n. sp.) n. fam. Rhynchostomida. Ein entoparasitisches Turbellar im Blut von Cypriniden. Zool. Anz. 29: 224-252.

RAšín K. 1929: [Janickia volgensis n. gen. n. sp., blood fluke from the fish Pelecus cultratus (L.)]. Biologické Spisy Vysoké Školy Zvěrolékařské Brno 8, No. 16, 21 pp. (In Czech, with German summary.)

Schell S.C. 1974: The life history of Sanguinicola idahoensis sp. n. (Trematoda: Sanguinicolidae), a blood parasite of steelhead trout, Salmo gairdneri Richardson. J. Parasitol. 60: 561566.

Sмiтн J.W. 1997a: The blood flukes (Digenea: Sanguinicolidae and Spirorchidae) of cold-blooded vertebrates: Part 1. A review of the published literature since 1971, and bibliography. Helminthol. Abst. 66: 255-294.

Sмiтн J.W. 1997b: The blood flukes (Digenea: Sanguinicolidae and Spirorchidae) of cold-blooded vertebrates: Part 2. Appendix I: Comprehensive parasite-host list; Appendix II: Comprehensive host-parasite list. Helminthol. Abst. 66: 329-344.

Szidat L. 1951: Neue Arten der Termatodenfamilie Aporocotylidae aus dem Blut und der Leibeshöhle von Süsswasserfischen des Rio de la Plata. Z. f. Parasitendk. 15: 70-86.

Woodland W.N.F. 1923: Sanguinicola from the Sudan. Quart. J. Microsc. Sci., New Series 67: 233-242.

Woodland W.N.F. 1924: Note on Sanguinicola from the Sudan: a correction. Quart. J. Microscop. Sci., New Series 68: 411-412.

Accepted 2 February 2013

Received 13 November 2012 